\title{
Belimumab: therapeutic mechanism and current status of clinical trials.
}

\author{
Dhilleswara Rao Vana* \\ Center for Excellence in Genomics, Madurai Kamaraj University, Tamil Nadu, India
}

\begin{abstract}
Systemic lupus erythematosus (SLE) is a chronic autoimmune disorder with diverse clinical features and involving multiple organs leading to highest mortality rate among rheumatic diseases. $B$ cells are responsible and central to the pathogenesis of SLE progression by means of over-aggressive immune response. The complexity of clinical manifestations and unpredictability of the disease are the main hurdles in optimizing treatment for SLE. Recent developments in biological therapy generated hope in SLE patients. Belimumab (Benlysta ${ }^{\circledR}$ ) is a complete human monoclonal antibody that is approved for SLE treatment. More or less, belimumab is the first approved biological drug from the Food and Drug Administration, United States (FDA), inhibiting B-cell activating factor/B-lymphocyte stimulator. The present review elucidates the cellular mechanism involved in SLE progression and therapeutic effective of belimumab including clinical trials and clinical outcomes.
\end{abstract}

Keywords: Belimumab, Systemic lupus erythematosus (SLE), BAFFF, APRIL.

Accepted on August 29, 2018

\section{Introduction}

Based on the epidemiological studies it was estimated that the prevalence of SLE was highest in North America affecting 241 per 100,000 people and the lowest incidence was observed in South Africa at the rate of 0.3 per 100,000 person-years. SLE affected more women than men for all age and ethnic groups [1]. Autoimmune diseases remained largely underexplored due to lack of complete knowledge about the pathogenesis, underlying mechanisms and treatment options; hence, these gaps of laboratory and clinically verified information are summing up as one of the major public health concerns [2]. The mortality rates due to systemic autoimmune diseases are significant and rising; mortality among SLE patients continued to rise in association with comorbidities such as cardiovascular diseases. However, there are many factors that influence the mortality rate; an international cohort published in 2006 indicated that the major risk factors associated are female sex, younger age, shorter SLE duration and circulatory disease. A Canadian cohort showed the mortality associated with cerebrovascular diseases in SLE patients [3-5].

In the recent past, there is an increased interest in understanding the immunopathogenesis of many autoimmune disorders including SLE. B cells are functioning in many directions such as antigen presenting cells, secreting proinflammatory cytokines and producing antibodies in healthy individuals. However, in SLE patients, B cells failed to distinguish self and non-self-antigens, which resulted in the over-production of antibodies against autoantigens and triggered the over-activation of the inflammatory response [6-9]. B cell activation factor (BAFF) is also known as Blymphocyte stimulator (BlyS) is the key factor in B cell differentiation, overexpression of BAFF is the salient feature of SLE, which further results in autoimmune $B$ cell proliferation subsequently, causing SLE. Through toll-likereceptor dependent and independent mechanisms, BAFF and type I interferons act together in SLE patients. Studies with mouse models confirmed overproduction of BAFF in SLE condition and defective signals for apoptosis in B cells was also observed [10,11].

\section{B-cell Activating Factor Mechanism}

BAFF is Tumor Necrosis Factor (TNF) super family ligand, produced by a wide range of cells and plays a key role in development and hemostasis of B-cells. BAFFs is available in two forms namely membrane bound and soluble forms among, which soluble form of BAFFs are biologically active. BAFF is a 285 amino acid cytokine family member, which is physiologically significant in B cell homeostasis and closely (50\% homology) resembles APRIL, which is a TNF superfamily member expressed on cells involved in innate immunity $[12,13]$. Both BAFF and APRIL are trimeric forms and bind to the receptor transmembrane activator, calcium modulator, and cyclophilin ligand interactor. BAFF has an affinity to bind with three different receptors that are presented on B-cell namely BAFF-R, transmembrane activator and CAML interactor (TACI), and B-cell maturation antigen (BCMA). As far as binding affinity is concerned, in SLE, the interaction between BAFFR and BAFF is stronger than interaction with the other two receptors. But it is believed that interaction with APRIL, a "proliferation-inducing ligand" receptors (TACI and BCAM) play vital roles in the pathogenesis of other autoimmune diseases including 
rheumatoid arthritis (RA), Sjogren's syndrome antineutrophil cytoplasmic antibody-associated vasculitis $[12,13]$. In disease pathological conditions, BAFF is responsible for the production of autoantibodies, which results in the development of SLE $[12,13]$.

The binding affinities of BAFF and APRIL to the receptors are different, however, all these receptors signal through TNF receptor-associated factors (TRAFs), NFאB and other pathways. BAFF-R (BAFF receptor 3) activates alternative $\mathrm{NF} \kappa \mathrm{B}$ pathways while the other 2 receptors BCMA and TACI activate classical NFKB [14]. BAFF-R is a recent addition to BAFF family receptors and significant role in $\mathrm{B}$ cell activities whereas neither TACI nor BCMA can influence the activity. Evidence suggests that the BAFF-R interactions with TRAFs and initiate the downstream signaling pathways which further results in non-classical pathway activation and subsequent upregulation of $\mathrm{Bcl}-2$ family members [14,15].

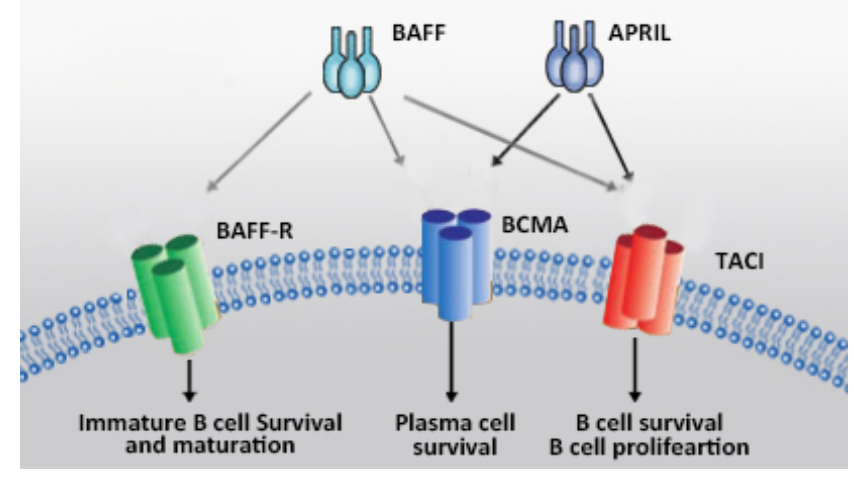

Figure 1. B-cell activation factor and A Proliferation-Inducing Ligand (APRIL) mechanism in normal conditions. BAFF binds to the receptors, BAFF-R, BCMA and TACI leading to immature $B$ cell survival and maturation, plasma cell survival and $B$ cell survival and proliferation, respectively, whereas APRIL binds with only BCMA and TACI leading to plasma cell survival and B cell survival and proliferation.

In early developmental stages of B cells, the BAFF and BAFF$\mathrm{R}$ signaling are important for survival by inhibiting the apoptosis which results in further allow B cells to differentiate as mature B cells on the other hand antigen-expressing B cell subsets are independent to the BAFF and B BAFF-R and depends on TACI and BCMA interaction. In this context, TACI interaction is an essential mechanism for $\mathrm{T}$ cell independent type II humoral responses, while the long lived B cells expressed BCMA of bone marrow and promote B cell survival and function (Figure 1) [14,15]. It has been reported in BAFF transgenic mice and murine models that the development of immunological and clinical parameters of SLE such a B-cell hyperplasia, autoantibodies, anti-double-stranded DNA (antidsDNA) antibodies and other autoimmune symptoms. In addition, many mice model studies reported that the target organ damage in SLE depend on the inflammatory burden imposed by activated cells and the mediators [16-19]. Furthermore, serum concentrations of BAFF in patients with SLE have shown higher levels when compared to healthy individuals. Serum concentrations of BAFF levels are higher in
African-American SLE patients than Caucasian SLE patients but there were no significant differences observed [20,21]. BAFF can bind to three different receptors that play a crucial role in $\mathrm{B}$ cell maturation [7,22]. Hence, agents inhibit the binding of BAFF to the receptors of B cells are in great demand [23].

\section{Belimumab (Benlysta ${ }^{\circledR}$ )}

Since 1955, hydroxychloroquine was approved as biological agent. After 50 years of research and development, in modern era, belimumab is the first ever biological agent (Hydroxychloroquine, approved in 1955) that has been approved by the USFDA in March 2011 and subsequently by European Medicines Agency in July 2011 for the treatment of SLE. Belimumab is a complete human $\operatorname{IgG} 1 \lambda$ recombinant monoclonal antibody which directs against BAFF and also indicated as an add-on therapy for the treatment of adult patients with active autoantibody positive, SLE and for patients receiving standard therapy, however, not indicated for severe active lupus nephritis or active Central Nervous System (CNS) lupus patients $[24,25]$.

\section{Therapeutic Mechanism and Dosage}

The cellular mechanisms underlying in SLE progression is clear, which allowed to identify potential therapeutic targets. Inhibiting the biological activity of BAFF and targeting B cell signaling and maturation belimumab is able to reduce the pathological complication related to SLE. As shown in Figure 2 , belimumab inhibits the binding of BAFF with BAFF-R by which the auto-B cell maturation inhibited; however, APRIL binding activity is not effected; hence, the survival and proliferation of plasma cells and B cells are not affected. Moreover, belimumab inhibits the prolonged antibody memory by blocking the transition of plasma cells to long lived plasma cells [26].

BAFF belongs to the tumor necrosis factor (TNF) ligand family. BAFF causes B-cell apoptosis leading to pathogenesis of SLE. Higher levels of BAFF are generally found in SLE patients with increased pathogenesis and antidouble-stranded DNA antibody titers. Therefore, inhibiting the biological activity of BAFF has a potential for the treatment of SLE. Belimumab is a recombinant monoclonal antibody which specifically acts against BAFF by binding to soluble BAFF. In lymphoid tissue, Belimumab can be able to block BAFFmediated maintenance of germinal reaction which further prevents the progression of $\mathrm{B}$ cell into high affinity memory cells. Belimumab can also block BAFF-induced $\mathrm{T}$ cell secretion INF- $\gamma$ and IL-2 and also IL-2 dependent $\mathrm{T}$ cell proliferation. These unique mechanisms made belimumab as a promising therapeutic option for SLE patients $[15,24,27,28]$

The approved dosage range upto $10 \mathrm{mg} / \mathrm{kg}$ at $2 \mathrm{w}$ interval for first 3 doses and $4 \mathrm{w}$ interval thereafter. Belimumab was recommended to administer intravenously and based on the estimation with set of action for suppression of B cell over $8 \mathrm{w}$ improvement in the clinical manifestations was found in $16 \mathrm{w}$ 
[29]. In clinical trials, more deaths have been reported and in controlled clinical trials, upper respiratory tract infection, urinary tract infection, nasopharyngitis, sinusitis, bronchitis, and influenza are identified as serious infections and also hypersensitivity reactions are also reported. Moreover, depression, insomnia, anxiety and suicidal behaviors are also observed [29].

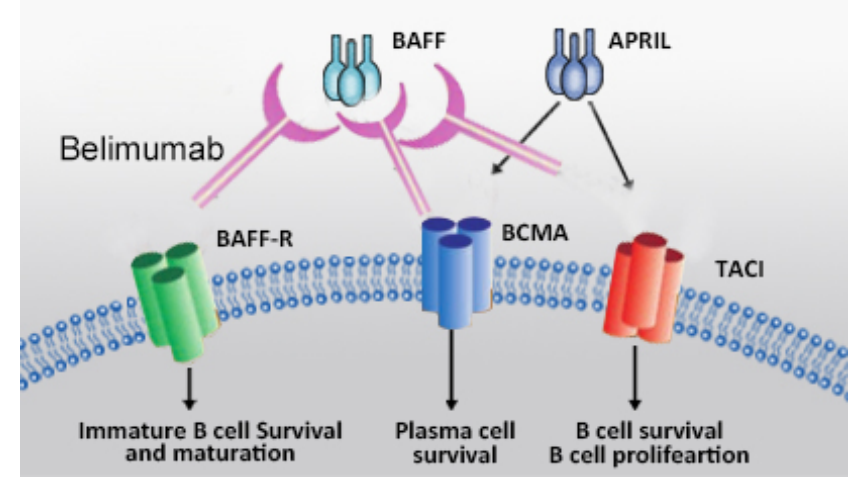

Figure 2. Therapeutic mechanism of belimumab which inhibits $B A F F$ binding to its receptors. APRIL retains its binding with BCMA and TACI.

Certain important highlights pertaining to the clinical trials regarding belimumab are presented in Table 1. Evidence from clinical studies, controlled studies, combined analysis of trials, retrospective analysis, post-hoc analyses, meta-analyses, observational data, cohort studies and cross-sectional studies are of interest whereas case reports, review articles, nonclinical data, duplicate and or overlapping studies are excluded from the list. Search methodology included and mostly studies from the search engine 'PubMed' have been referred.

\section{Clinical Trails}

Chatham et al. studied the effect of belimumab on pre-existing vaccine antigen antibodies in SLE patients and observed that proportion of patients having antibody responses to pneumococcal, tetanus, and influenza antigens did not decrease. The study group have evaluated the effect of belimumab on immune response to pneumococcal vaccination among SLE patients and observed that the proportion of patients with response to more than one pneumococcal serotype were similar across pre-belimumab and belimumabconcurrent cohorts [30]. van Vollenhoven et al. studied the effect of belimumab on corticosteroid dose in SLE patients and found that cumulative corticosteroid dose was substantially smaller than placebo group indicating the belimumab may be steroid sparing [31]. Schwarting et al. demonstrated the efficacy and safety of belimumab in combination with standard of care for different grouping of steroid, anti-malarials, and immunosuppressants and observed that overall safety was similar across concomitant medication groups except serious adverse events in the steroids plus antimalarial group [32]. Strand et al. have reported the effects of belimumab treatment and standard SLE therapy and found that the disease activity has in fact reduced along with improvement in health related quality of life [33]. Kandala et al. reported a review and metaanalysis of clinical effectiveness of belimumab for SLE patients and antinuclear and/or anti-double stranded DNA autoantibodies and observed benefit for belimumab [34]. Petri et al. studied baseline predictors for moderate to severe SLE flares and evaluated the effect of standard therapy on prevention. The study observed that patients with renal, neurologic and vasculitic involvement, elevated anti-dsDNA or BLys levels or low $\mathrm{C} 3$ have shown increased risk of flare over one year [35]. Chatham et al. [36] studied effect of belimumab on vaccine antigen antibodies to influenza, pneumococcal, and tetanus vaccines in patients with systemic lupus erythematosus in the BLISS-76 trial. Manzi et al. [37] studied Effects of belimumab, a B lymphocyte stimulator-specific inhibitor, on disease activity across multiple organ domains in patients with systemic lupus erythematosus: combined results from two phase III trials. Furie et al. analysed the efficacy of belimumab and standard therapy on active SLE and found that the treatment improved the SLE responder index rate and reduced SLE disease activity. Based on SLE responder index at $52 \mathrm{w}$, Navarra et al. have noted that belimumab had the potential to be a novel option for management of SLE; however, serious infection and hypersensitivity are also observed [38,39].

\section{Search methodology}

' $<<$ Belimumab $>$ ', ' $<<$ Phase III Belimumab $>>$ ', ' $<<$ Phase IIIB Belimumab $>>$ ', ' $<<$ Phase IV Belimumab $>>$ ', ' $<<$ Post marketing Belimumab $>>$

Table 1. Clinical trials and outcome.

\begin{tabular}{|c|c|c|c|c|}
\hline Year & Title & Study type & Clinical outcomes & References \\
\hline 2011 & $\begin{array}{l}\text { Efficacy and safety of belimumab in patients with } \\
\text { active systemic lupus erythematosus: a } \\
\text { randomised, placebo-controlled, phase } 3 \text { trial }\end{array}$ & $\begin{array}{l}\text { Randomised, placebo-controlled } \\
\text { multicentre phase } 3 \text { study }\end{array}$ & $\begin{array}{l}\text { No malignant diseases were } \\
\text { reported, serious infections, serious } \\
\text { hypersensitivity reactions }\end{array}$ & Navarra et al. [38] \\
\hline 2011 & $\begin{array}{l}\text { A phase III, randomized, placebo-controlled study } \\
\text { of belimumab, a monoclonal antibody that inhibits } \\
\text { B lymphocyte stimulator, in patients with systemic } \\
\text { lupus erythematosus }\end{array}$ & $\begin{array}{l}\text { A phase III, randomized, placebo- } \\
\text { controlled study }\end{array}$ & $\begin{array}{l}\text { AEs, including infections, } \\
\text { malignancies, and deaths }\end{array}$ & Furie et al. [39] \\
\hline 2012 & $\begin{array}{l}\text { Effect of belimumab on vaccine antigen antibodies } \\
\text { to influenza, pneumococcal, and tetanus vaccines } \\
\text { in patients with systemic lupus erythematosus in } \\
\text { the BLISS- } 76 \text { trial }\end{array}$ & $\begin{array}{l}\text { Sub-study from the phase III, } \\
\text { randomized, double-blind, placebo- } \\
\text { controlled BLISS-76 trial pf belimumab }\end{array}$ & None & Chatham et al. [36] \\
\hline
\end{tabular}




\begin{tabular}{|c|c|c|c|c|}
\hline 2012 & $\begin{array}{l}\text { Effects of belimumab, a B lymphocyte stimulator- } \\
\text { specific inhibitor, on disease activity across } \\
\text { multiple organ domains in patients with systemic } \\
\text { lupus erythematosus: combined results from two } \\
\text { phase III trials }\end{array}$ & $\begin{array}{l}\text { Two phase III trials (BLISS- } 52 \text { and } \\
\text { BLISS-76) comparing belimumab } \\
\text { efficacy on SLE }\end{array}$ & None & Manzi et al. [37] \\
\hline 2013 & $\begin{array}{l}\text { Belimumab: a technological advance for systemic } \\
\text { lupus erythematosus patients? Report of a } \\
\text { systematic review and meta-analysis }\end{array}$ & $\begin{array}{l}\text { A meta-analysis of randomised } \\
\text { controlled trials }\end{array}$ & None & Kandala et al. [34] \\
\hline 2013 & $\begin{array}{l}\text { Baseline predictors of systemic lupus } \\
\text { erythematosus flares: data from the combined } \\
\text { placebo groups in the phase III belimumab trials }\end{array}$ & $\begin{array}{l}\text { Phase III belimumab trial; the impact of } \\
\text { standard therapies on SLE }\end{array}$ & Neurologic events & Petri et al. [35] \\
\hline 2014 & $\begin{array}{l}\text { Improvements in health-related quality of life with } \\
\text { Belimumab, a B-lymphocyte stimulator-specific } \\
\text { inhibitor, in patients with autoantibody-positive } \\
\text { systemic lupus erythematosus from the } \\
\text { randomised controlled BLISS trials. }\end{array}$ & $\begin{array}{l}\text { Two multicentre, randomised controlled } \\
\text { trials }\end{array}$ & None & Strand et al. [33] \\
\hline 2016 & $\begin{array}{l}\text { Cumulative corticosteroid dose over fifty-two } \\
\text { weeks in patients with systemic lupus } \\
\text { erythematosus: pooled analyses from the phase } \\
\text { III belimumab trials. }\end{array}$ & $\begin{array}{l}\text { Randomized, controlled trials, analysed } \\
\text { the effects of treatment with belimumab } \\
\text { on corticosteroid dose in patients with } \\
\text { SLE }\end{array}$ & $\begin{array}{l}\text { Headache, upper respiratory tract } \\
\text { infection, arthralgia, and urinary tract } \\
\text { infection }\end{array}$ & $\begin{array}{l}\text { van Vollenhoven et al. } \\
\text { [31] }\end{array}$ \\
\hline 2016 & $\begin{array}{l}\text { Impact of concomitant medication use on } \\
\text { belimumab efficacy and safety in patients with } \\
\text { systemic lupus erythematosus. }\end{array}$ & $\begin{array}{l}\text { Phase III, randomized trials; post hoc } \\
\text { analysis on efficacy and safety data for } \\
\text { belimumab. }\end{array}$ & $\begin{array}{l}\text { Treatment-emergent AEs, } \\
\text { headache, upper respiratory tract } \\
\text { infection, arthralgia, nasopharyngitis, } \\
\text { urinary tract infection, diarrhea, } \\
\text { nausea and fatigue }\end{array}$ & Schwarting et al. [32] \\
\hline \multirow[t]{2}{*}{2017} & \multirow{2}{*}{$\begin{array}{l}\text { A randomized, open-label study to investigate the } \\
\text { effect of belimumab on pneumococcal vaccination } \\
\text { in patients with active, autoantibody-positive } \\
\text { systemic lupus erythematosus. }\end{array}$} & \multirow[t]{2}{*}{ Randomized, phase 4, open-label study } & Non-fatal serious adverse events & \multirow[t]{2}{*}{ Chatham et al. [30] } \\
\hline & & & No deaths were reported & \\
\hline
\end{tabular}

\section{Conclusive Remarks}

In the recent past, targeted therapy evolved as a promising intervention for many deadly diseases such as cancer, autoimmune disorders, etc. In the context of SLE, it's been over 5 decades, there is no effective drug approved. Belimumab, the first ever biological approved for SLE treatment; however, there are few questions remain unanswered. It is believed that the monoclonal antibody therapy is one of the revolutionary tools in treating many autoimmune disorders, supporting belimumab has shown significant safety profiles in phase III clinical trials. Moreover, the post marketing studies also warranted the better guidelines for the physicians. In many clinical trials, belimumab showed modest effects with no significant adverse events, this success set a new stage to test more biological molecules against SLE and BAFF/APRIL axis. More clinical trial should be conducted to overcome the setbacks existed in belimumab treatment; therefore, in future, it can be the most reliable treatment option for SLE and associated complications.

\section{Acknowledgements}

The author expresses sincere thanks to Dr. VSS Prasad for providing support in editing the manuscript and technical inputs and Mr. Sathish Amudala for his beautiful graphical work.

\section{References}

1. Rees F, Doherty M, Grainge MJ, Lanyon P, Zhang W. The worldwide incidence and prevalence of systemic lupus erythematosus: a systematic review of epidemiological studies. Rheumatology 2017; 56: 1945-1961.

2. Shi G, Zhang J, Zhang Z, Zhang X. Systemic autoimmune diseases. Clin Dev Immunol 2013; 728574.

3. Fors Nieves CE, Izmirly PM. Mortality in systemic lupus erythematosus: an updated review. Curr Rheumatol Rep 2016; 18: 21.

4. Doria A, Iaccarino L, Ghirardello A, Zampieri S, Arienti S, Sarzi-Puttini P, Atzeni F, Piccoli A, Todesco S. Longterm prognosis and causes of death in systemic lupus erythematosus. Am J Med 2006; 119: 700-706.

5. Bernatsky S, Boivin JF, Joseph L, Manzi S, Ginzler E, Gladman DD, Urowitz M, Fortin PR, Petri M, Barr S, Gordon C, Bae SC, Isenberg D, Zoma A, Aranow C, Dooley MA, Nived O, Sturfelt G, Steinsson K, Alarcon G, Senecal JL, Zummer M, Hanly J, Ensworth S, Pope J, Edworthy S, Rahman A, Sibley J, El-Gabalawy H, McCarthy T, St Pierre Y, Clarke A, Ramsey-Goldman R. Mortality in systemic lupus erythematosus. Arthritis Rheum 2006; 54: 2550-2557.

6. Nashi E, Wang Y, Diamond B. The role of B cells in lupus pathogenesis. Int J Biochem Cell Biol 2010; 42: 543-550.

7. Vincent FB, Morand EF, Schneider P, Mackay F. The BAFF/APRIL system in SLE pathogenesis. Nat Rev Rheumatol 2014; 365-373. 
8. Kamal A, Khamashta M. The efficacy of novel B cell biologics as the future of SLE treatment: a review. Autoimmun Rev 2014; 13: 1094-1101.

9. Stephan B, Kathleen M, Rachel E, Josef S, Ronald H. Bcell targeted therapeutics in clinical development. Arthritis Res Ther 2013; 15: 4.

10. Mackay F, Woodcock SA, Lawton P, Ambrose C, Baetscher M, Schneider P, Tschopp J, Browning JL. Mice transgenic for BAFF develop lymphocytic disorders along with autoimmune manifestations. J Exp Med 1999; 190: 1697-1710.

11. Figgett WA, Fairfax K, Vincent FB, Le Page MA, Katik I, Deliyanti D, Quah PS, Verma P, Grumont R, Gerondakis S, Hertzog P, OReilly LA, Strasser A, Mackay F. The TACI receptor regulates T-cell-independent marginal zone B cell responses through innate activation-induced cell death. Immunity 2013; 573-583.

12. Treml JF, Hao Y, Stadanlick JE, Cancro MP. The BLyS family: toward a molecular understanding of B cell homeostasis. Cell Biochem Biophys 2009; 53: 1-16.

13. Lenert A, Lenert P. Current and emerging treatment options for ANCA-associated vasculitis: potential role of belimumab and other BAFF/APRIL targeting agents. Drug Des Devel Ther 2015; 9: 333-347.

14. Mackay F, Schneider P. Cracking the BAFF code. Nat Rev Immunol 2009; 9: 491-502.

15. John FT, Yi H, Jason ES, Michael PC. The BLyS family: toward a molecular understanding of B cell homeostasis. Cell Biochem Biophys 2009; 53: 1-16.

16. Ramanujam M, Davidson A. BAFF blockade for systemic lupus erythematosus: will the promise be fulfilled? Immunol Rev 2008; 223: 156-174.

17. Ramanujam M, Wang X, Huang W, Liu Z, Schiffer L, Tao H, Frank D, Rice J, Diamond B, Yu KO, Porcelli S, Davidson A. Similarities and differences between selective and nonselective BAFF blockade in murine SLE. J Clin Invest 2006; 116: 724-734.

18. Ramanujam M, Bethunaickan R, Huang W, Tao H, Madaio MP, Davidson A. Selective blockade of BAFF for the prevention and treatment of systemic lupus erythematosus nephritis in NZM2410 mice. Arthritis Rheum 2010; 62: 1457-1468.

19. Philip K, Meera R,1 Ramalingam B, Weiqing H, Haiou T, Michael PM, Stephen MF, Anne D. Prevention of murine antiphospholipid syndrome by BAFF blockade. Arthritis Rheum 2008; 58: 2824-2834.

20. Zhang J, Roschke V, Baker KP, Wang Z, Alarcon GS, Fessler BJ, Bastian H, Kimberly RP, Zhou T. Cutting edge: a role for $\mathrm{B}$ lymphocyte stimulator in systemic lupus erythematosus. J Immunol 2001; 166: 6-10.

21. Ritterhouse LL, Crowe SR, Niewold TB, Merrill JT, Roberts VC, Dedeke AB, Neas BR, Thompson LF, Guthridge JM, James JA. B lymphocyte stimulator levels in systemic lupus erythematosus: higher circulating levels in African American patients and increased production after influenza vaccination in patients with low baseline levels. Arthritis Rheum 2011; 63: 3931-3941.

22. Baker KP, Edwards BM, Main SH, Choi GH, Wager RE, Halpern WG, Lappin PB, Riccobene T, Abramian D, Sekut L, Sturm B, Poortman C, Minter RR, Dobson CL, Williams E, Carmen S, Smith R, Roschke V, Hilbert DM, Vaughan TJ, Albert VR. Generation and characterization of LymphoStat-B, a human monoclonal antibody that antagonizes the bioactivities of B lymphocyte stimulator. Arthritis Rheum 2003; 48: 3253-3265.

23. Espinosa G, Cervera R. Belimumab, a BLyS-specific inhibitor for the treatment of systemic lupus erythematosus. Drugs Today (Barc) 2010; 46: 891-899.

24. Dubey AK, Handu SS, Dubey S, Sharma P, Sharma KK, Ahmed QM. Belimumab: First targeted biological treatment for systemic lupus erythematosus. J Pharmacol Pharmacother 2011; 2: 317-319.

25. Stohl W, Hilbert DM. The discovery and development of belimumab: the anti-BLyS-lupus connection. Nat Biotechnol 2012; 30: 69-77.

26. Kim SS, Kirou KA, Erkan D. Belimumab in systemic lupus erythematosus: an update for clinicians. Ther Adv Chronic Dis 2012; 3: 11-23.

27. Dhaun N, Kluth DC. Belimumab for systemic lupus erythematosus. Lancet 2011; 377: 2079-2080.

28. Chung JB, Silverman M, Monroe JG. Transitional B cells: step by step towards immune competence. Trends Immunol 2003; 24: 343-349.

29. https: //www.accessdata.fda.gov/drugsatfda_docs/label/ 2011/125370s0000lbl.pdf

30. Chatham W, Chadha A, Fettiplace J, Kleoudis C, Bass D, Roth D, Gordon D. A randomized, open-label study to investigate the effect of Belimumab on pneumococcal vaccination in patients with active, autoantibody-positive systemic lupus erythematosus. Lupus 2017; 26.

31. van Vollenhoven RF, Petri M, Wallace DJ, Roth DA, Molta CT, Hammer AE, Tang Y, Thompson A. Cumulative corticosteroid dose over fifty-two weeks in patients with systemic lupus erythematosus: pooled analyses from the phase III belimumab trials. Arthritis Rheumatol 2016; 68: 2184-2192.

32. Schwarting A, Dooley MA, Roth DA, Edwards L, Thompson A, Wilson B. Impact of concomitant medication use on Belimumab efficacy and safety in patients with systemic lupus erythematosus. Lupus 2016; 25: 1587-1596.

33. Strand V, Levy RA, Cervera R, Petri MA, Birch H, Freimuth WW, Zhong ZJ, Clarke AE, BLISS-52 and -76 Study Groups. Improvements in health-related quality of life with Belimumab, a B-lymphocyte stimulator-specific inhibitor, in patients with autoantibody-positive systemic lupus erythematosus from the randomised controlled BLISS trials. Ann Rheum Dis 2014; 73: 838-844.

34. Ngianga BK, Martin C, Amy G, Paul S, Syed M, Louise H, Rachel C, Ewen C, Caroline G, Aileen C. Belimumab: a technological advance for systemic lupus erythematosus 
patients? Report of a systematic review and meta-analysis. Epidemiology 2013; 3: 002852.

35. Petri MA, van Vollenhoven RF, Buyon J, Levy RA, Navarra SV, Cervera R, Zhong ZJ, Freimuth WW, BLISS-52 and BLISS-76 Study Groups. Baseline predictors of systemic lupus erythematosus flares: data from the combined placebo groups in the phase III Belimumab trials. Arthritis Rheum 2013; 65: 2143-2153.

36. Chatham WW, Wallace DJ, Stohl W, Latinis KM, Manzi S, McCune WJ, Tegzova D, McKay JD, Avila-Armengol HE, Utset TO, Zhong ZJ, Hough DR, Freimuth WW, Migone TS, BLISS-76 Study Group. Effect of belimumab on vaccine antigen antibodies to influenza, pneumococcal, and tetanus vaccines in patients with systemic lupus erythematosus in the BLISS-76 trial. J Rheumatol 2012; 39: 1632-1640.

37. Manzi S, Sanchez-Guerrero J, Merrill JT, Furie R, Gladman D, Navarra SV, Ginzler EM, DCruz DP, Doria A, Cooper S, Zhong ZJ, Hough D, Freimuth W, Petri MA, BLISS-52 and BLISS-76 Study Groups. Effects of belimumab, a B lymphocyte stimulator-specific inhibitor, on disease activity across multiple organ domains in patients with systemic lupus erythematosus: combined results from two phase III trials. Ann Rheum Dis 2012; 71: 1833-1838.
38. Navarra SV, Guzman RM, Gallacher AE, Hall S, Levy RA, Jimenez RE, Li EK, Thomas M, Kim HY, León MG, Tanasescu C, Nasonov E, Lan JL, Pineda L, Zhong ZJ, Freimuth W, Petri MA; BLISS-52 Study Group. Efficacy and safety of Belimumab in patients with active systemic lupus erythematosus: a randomised, placebo-controlled, phase 3 trial. Lancet 2011; 377: 721-731.

39. Furie R, Petri M, Zamani O, Cervera R, Wallace DJ, Tegzova D, Sanchez-Guerrero J, Schwarting A, Merrill JT, Chatham WW, Stohl W, Ginzler EM, Hough DR, Zhong ZJ, Freimuth W, van Vollenhoven RF, BLISS-76 Study Group. A phase III, randomized, placebo-controlled study of Belimumab, a monoclonal antibody that inhibits B lymphocyte stimulator, in patients with systemic lupus erythematosus. Arthritis Rheum 2011; 63: 3918-3930.

\section{*Correspondence to}

Dhilleswara Rao Vana

Center for Excellence in Genomics

Madurai Kamaraj University

Tamil Nadu

India 